\title{
Headache management for the pain specialist
}

Avi Ashkenazi

Thomas Jefferson University

Stephen Silberstein

Thomas Jefferson University

Follow this and additional works at: https://jdc.jefferson.edu/neurologyfp

Part of the Neurology Commons

Let us know how access to this document benefits you

\section{Recommended Citation}

Ashkenazi, Avi and Silberstein, Stephen, "Headache management for the pain specialist" (2004).

Department of Neurology Faculty Papers. Paper 12.

https://jdc.jefferson.edu/neurologyfp/12

This Article is brought to you for free and open access by the Jefferson Digital Commons. The Jefferson Digital Commons is a service of Thomas Jefferson University's Center for Teaching and Learning (CTL). The Commons is a showcase for Jefferson books and journals, peer-reviewed scholarly publications, unique historical collections from the University archives, and teaching tools. The Jefferson Digital Commons allows researchers and interested readers anywhere in the world to learn about and keep up to date with Jefferson scholarship. This article has been accepted for inclusion in Department of Neurology Faculty Papers by an authorized administrator of the Jefferson Digital Commons. For more information, please contact: JeffersonDigitalCommons@jefferson.edu. 


\title{
Headache Management for the Pain Specialist
}

\author{
Avi Ashkenazi, M.D. \\ Jefferson Headache Center \\ Thomas Jefferson University Hospital \\ Philadelphia, Pennsylvania \\ Stephen D. Silberstein, M.D., F.A.C.P. \\ Director, Jefferson Headache Center, \\ and Professor of Neurology \\ Thomas Jefferson University Hospital \\ Philadelphia, Pennsylvania
}

Send reprints and correspondence to:

Avi Ashkenazi, M.D.

Jefferson Headache Center

Thomas Jefferson University Hospital

Gibbon Building, Suite 8130

111 South 11th Street Philadelphia, Pennsylvania 19107

Tel: 215-955-2032; Fax: 215-955-2060

Email: avi.ashkenazi@mail.tju.edu

Running title: Headache for the Anesthesiologist

Key words: $\quad$ migraine; cluster headache; tension-type headache; cervicogenic

headache; post-dural puncture headache; nerve block 


\begin{abstract}
Headache is a common symptom caused by a wide variety of diseases. Primary headaches include migraine, cluster headache, tension-type headache and other less common diseases. It is important to differentiate these headaches from secondary headaches caused by vascular, neoplastic, infectious, metabolic and toxic disorders. Most primary headaches have a genetic basis, with environmental factors acting as triggers. Recent advances in basic research resulted in the development of more specific and effective therapies. Medication overuse headache is a very common cause of chronic daily headache. Detoxification from the offending drug is essential for headache improvement. Cervicogenic headache is common and needs to be diagnosed correctly since it may require specific therapy. Nerve blocks are useful for some patients with primary, as well as secondary, headaches.
\end{abstract}




\section{Introduction}

Headache is a very common symptom, with a life time prevalence approaching $100 \%$. Most headaches are caused by benign (yet sometimes incapacitating) diseases like migraine and tension-type headache. Life-threatening causes of headache are less frequent but important to recognize. Recent progress in the understanding of headache mechanisms has led to the development of new and effective treatments for primary headaches.

In this review we will discuss the clinical features and treatment of common primary headaches, as well as of secondary headaches that are of special interest to the anesthesiologist. We will also discuss symptoms and signs that should prompt a search for a potentially life-threatening cause of headache. Finally, we review peripheral nerve blocks as a treatment for headaches.

\section{Primary headaches}

Primary headaches are a disorder unto themselves. They are defined by the characteristics of the headache and its associated symptoms.

\section{Migraine}


Migraine is a neurovascular disorder characterized by episodes of headache accompanied by various combinations of gastrointestinal symptoms, autonomic nervous system dysfunction and, in some patients, an aura consisting of transient neurologic symptoms $[1,2]$.

\section{Epidemiology}

Migraine is a very common disorder with a one-year prevalence of $12 \%$ in the adult population (18\% in women and $6 \%$ in men) and $4 \%$ in children in the US and Western Europe [3]. Migraine prevalence is highest between the ages of 25 and 55 years, which are the years of peak productivity [4]. This age distribution, along with the high disability caused by migraine in a significant proportion of patients, explains the high economic impact of the disease. The World Health Organization (WHO) rates migraine as one of the most disabling chronic diseases [5].

\section{Clinical features}

The two major subtypes of migraine are migraine without aura (MO) and migraine with aura (MA) [6]. Patients with both MO and MA may experience premonitory symptoms several hours to days before the attack. These include fatigue, depression, cognitive dysfunction and food craving [7]. 
MO is the most common subtype of migraine. It typically manifests as recurrent episodes of moderate to severe unilateral headache which is throbbing in quality and aggravated by physical activity. The headache may be associated with nausea or vomiting and/or photophobia and phonophobia. Migraine headache, however, may be non-throbbing or bilateral [1]. According to the International Headache Society (IHS) criteria, these episodes should last 4-72 hours (Appendix 1). A migraine attack that lasts more than 72 hours is defined as status migrainosus.

MA manifests as attacks of headache similar to those of MO that are preceded by reversible focal neurologic symptoms called aura (Appendix 2). The aura develops gradually over 5-20 minutes and usually lasts for less than 60 minutes. The most common type of aura is visual, manifesting as scotoma (partial loss of vision), photopsia (unformed flashes of light) or fortification spectra (zig-zag lines). Less commonly, aura may be sensory (paresthesias), motor (focal weakness) or involve language function. Usually the aura precede the headache, but occasionally it appears simultaneously with it. In other, less common, cases the aura may occur without the headache.

Migraine attacks can occur from once in several months to several times a week and can last from few hours to several days. Headache severity ranges from moderate to completely incapacitating. Following the attack the patient may feel tired, irritable and listless.

\section{Pathophysiology}


Migraine is currently considered a primary brain disorder with secondary involvement of meningeal blood vessels $[2,8]$. There is evidence for a generator of migraine attacks in the upper brainstem, probably involving nuclei that modulate craniovascular pain afferents [9]. During an attack trigeminal sensory neurons are activated and release substance $\mathrm{P}$, calcitonin gene related peptide (CGRP) and neurokinin A. This results in neurogenic inflammation, meningeal blood vessel dilatation and plasma protein extravasation. Some of these processes are mediated by serotonin, released from trigeminal nerve endings adjacent to meningeal blood vessels [10]. There is also evidence for sensitization of neurons in the trigeminal nucleus caudalis (TNC) in animal models of headache that may apply to migraine [11]. Clinically, during migraine attacks patients may experience cutaneous allodynia, probably related to central sensitization [12]. Migraine aura appears to be related to the phenomenon of cortical spreading depression described by Leão [13]. Aura is associated with neuronal events which reduce cerebral activity and with a wave of spreading oligemia that advances across the cerebral cortex from the occipital area forward at a characteristic rate of $2-3 \mathrm{~mm} / \mathrm{min}$. This oligemia is preceded by a short phase of hyperemia due to CNS activation and is not confined to specific blood vessel territories [14].

There is a known genetic predisposition to migraine. The relative risk of first degree relatives of migraine patients to suffer from the disease is 1.9 for $\mathrm{MO}$ and 3.8 for MA $[15]$.

\section{Management}




\section{Initial approach to the headache patient}

The management of migraine begins with making a correct diagnosis. Laboratory and imaging studies should be done in the appropriate cases to exclude secondary causes of headache [16]. Symptoms, signs and clinical settings that should raise suspicion of a worrisome underlying disease include (Table 1):

1. New onset of headache in a patient older than 50 years.

2. The sudden onset of headache.

3. The occurrence of the worst headache ever.

4. A progressively-worsening headache.

5. Headache in a patient with cancer or AIDS.

6. Headache with fever or rash.

7. Headache with papilledema.

8. Headache with focal neurologic signs.

In any of the above cases, a neurologic consultation should be obtained and the proper tests (e.g. neuroimaging, lumbar puncture, ESR) performed. Neuroimaging is not usually recommended for patients with a typical clinical picture of migraine and a normal neurologic examination [17].

Once the diagnosis of migraine is established, it should be explained to the patient and a treatment plan developed. Triggers for migraine attacks, such as emotional or mental 
stress, poor sleep patterns, skipped meals and hormonal changes in women, should be addressed and corrected or avoided if possible.

\section{Drug therapy}

Migraine pharmacotherapy may be acute, to reverse the symptoms of the acute attack or preventive, to reduce the frequency, severity and duration of attacks.

\section{Treatment of the acute attack}

Acute migraine treatment can be divided into non-specific (drugs that are used to treat various pain disorders) and migraine-specific drugs. The non-specific drugs include acetaminophen, aspirin, non-steroidal anti-inflammatory drugs (NSAIDs), opiates and anti-emetic drugs. The migraine-specific drugs include the ergots and the $5 \mathrm{HT}_{1 \mathrm{~B} / 1 \mathrm{D}}$ agonists known as the triptans.

Several principles should be followed in acute migraine treatment. 1 . The drug should be taken as early as possible into the attack. This will increase treatment efficacy and accelerate the clinical response [18] [19]. 2. The dose should be adequate (e.g. $1000 \mathrm{mg}$ of acetaminophen;s 500-1000 mg of naproxen). 3. The route of administration should be appropriate. For patients with severe nausea or vomiting a parenteral route is preferred. 4. The number of treatments should be limited to 2-3/week to avoid analgesic-overuse headache. The choice of drug and route of administration for the individual patient 
depend on the severity of the attack, its rate of evolvement, associated symptoms and coexisting diseases.

\section{Non-specific drugs}

NSAIDs and other simple analgesics are effective for some migraineurs [1]. Opioid use should be minimized due to the potential risks of drug overuse with resultant headache exacerbation [20]. It has been recently suggested that opioid therapy should not be the first line treatment for acute headache in an emergency department setting [21]. An analysis of 160 refractory headache patients treated with daily scheduled opioids (DSO) in a referral headache center was recently performed [22]. Only $26 \%$ of the patients had $>50 \%$ headache improvement. Despite careful screening and patient selection, problematic drug behavior occurred in $50 \%$ of patients, the most common of which was dose violation. The authors concluded that opioid therapy may provide significant long term relief to selected patients, although most subjects did not improve with this treatment.

Several anti-emetics and neuroleptics are effective for acute migraine treatment.

Prochlorperazine, chlorpromazine, promethazine or metoclopramide can be used for both migraine headache and associated nausea and vomiting [23-25]. Droperidol, a potent dopamine receptor antagonist, has recently been found effective for acute migraine treatment at a dose of $2.75 \mathrm{mg}$ intramuscularly [26]. Droperidol is associated with a dosedependent prolongation of the QT interval. This effect may be seen within 10 minutes of drug administration [27]. There is a black box warning for droperidol (Inapsine) stating 
that : "cases of QT prolongation and/or torsades de pointes have been reported in patients receiving inapsine at doses at or below recommended doses. Some cases occurred in patients with no known risk factors for QT prolongation and some cases have been fatal" [27]. QT interval, as well as calcium and potassium blood levels should be measured before treatment [28].

\section{Migraine-specific drugs}

\section{Ergot derivatives}

Ergots have been used for migraine treatment for over 50 years [29]. Since the introduction of the more pharmacologically-specific triptans, the justification for their use has decreased. They remain, however, useful for some patients with prolonged attacks or high headache recurrence rates. Dihydroergotamine (DHE) has fewer adverse events and is less likely to produce rebound headache compared with ergotamine. It can be given intranasally or intramuscularly in an out patient setting. Repetitive intravenous DHE is the mainstay of treatment for refractory migraine in an inpatient setting [30].

\section{Triptans}

The development of the triptans and their introduction to clinical use in the early 1990s have dramatically changed acute migraine treatment $[2,28]$. The triptans have a more specific pharmacologic profile than the ergots and their efficacy has been established in 
well-designed clinical trials. There are currently seven triptans available for acute migraine treatment: sumatriptan, zolmitriptan, naratriptan, rizatriptan, almotriptan, frovatriptan and eletriptan (Table 2). Triptans are $5 \mathrm{HT}_{1 \mathrm{~B} / 1 \mathrm{D}}$ receptor agonists. They relieve symptoms of acute migraine attack by several mechanisms: vasoconstriction of meningeal vessels, inhibition of primary trigeminal afferent fibers and inhibition of second-order neurons in the TNC [2]. The triptans differ in their pharmacokinetics, available formulations and, to some extent, efficacy and tolerability. All triptans are available in an oral formulation. Some (rizatriptan, zolmitriptan) are also available in an orally-dissolved formulation and some as a nasal spray (sumatriptan, zolmitriptan). Sumatriptan can also be injected subcutaneously. The triptans are effective and welltolerated for acute migraine treatment. Common side effects include dizziness, paresthesias, warmth sensation and chest pressure, which is probably non-cardiac in origin. Although 5-HT ${ }_{1 \mathrm{~B}}$ receptors have been found in the coronary circulation, the triptans have proved to be very safe drugs with rare reports of adverse cardiovascular events [31]. Still, they are contraindicated in patients with ischemic heart disease, cerebrovascular disease, uncontrolled hypertension and hemiplegic or basilar migraine.

\section{Preventive treatment}

Preventive drug therapy is given to reduce attack frequency, duration and severity [32]. It may also render migraine attacks more responsive to acute treatment. Indications for starting preventive treatment include: migraine that significantly interferes with the patient's daily routine despite acute treatment; failure of-, contraindication to-, or 
troublesome adverse events from acute medications; acute medication overuse; very frequent headaches $(>2 /$ week); patient preference; hemiplegic migraine or attacks with a risk of permanent neurologic injury [33]. Drugs that are used for migraine prevention include the $\beta$-adrenergic blockers, antidepressants, anticonvulsants, calcium channel blockers, serotonin antagonists and NSAIDs (Table 3) [1]. The choice of a preventive drug is based on efficacy, prior patient exposure, adverse-event profile, comorbidity and concomitant drug therapy. In general, preventive drugs are started at a low dose that is increased gradually while monitoring tolerability and efficacy. Patients should be advised that a full therapeutic response may take several weeks to months to occur.

Recently, Botulinum toxin type A (BTX-A, Botox $\left.{ }^{\circledR}\right)$ was found to be effective for migraine prophylaxis $[28,34]$. The toxin is injected intramuscularly at different sites in the head or neck. Common injection sites are the glabellar, frontalis, and temporalis muscles. Treatment with BTX-A is safe, well-tolerated and has a long duration of action (of up to four months). It is particularly appealing for patients who have poor compliance, or are intolerant, to daily drug treatment. Side effects are transient and include blepharoptosis, diplopia and injection site weakness. Non-pharmacologic preventive strategies include relaxation training, biofeedback and cognitive-behavioral therapy [35].

\section{Cluster headache}

Cluster headache $(\mathrm{CH})$ is the most painful of the primary headaches [36,37]. It is characterized by episodes of severe, strictly unilateral headache associated with 
symptoms and signs of cranial parasympathetic hyperactivity and sympathetic dysfunction.

\section{Epidemiology}

$\mathrm{CH}$ is less common than migraine, with an estimated prevalence of $0.4 \%$ [36]. In contrast to migraine, it is more common in men than in women, with a gender ratio of approximately 5:1. Recent studies, however, suggest that this ratio is decreasing [38]. The disease onset is usually in the third decade.

\section{Clinical features}

The hallmark of $\mathrm{CH}$ is its periodicity. In most patients attacks occur during specific times called cluster periods. These periods last for several weeks to months and are separated by remission periods that may last several weeks to many years [36]. In many patients cluster periods occur with striking regularity at the same time of the year. A minority (10\%) of patients have only short remission periods (lasting less than one month) or none at all. They are classified as having chronic (as opposed to episodic) $\mathrm{CH}$.

During a cluster period the attack frequency ranges from one every other day to eight per day. $\mathrm{CH}$ attack is characterized by a rapidly developing, severe, unilateral pain in the periorbital, temporal or frontal area. The pain usually lasts $45-90$ minutes and is associated with symptoms and signs of autonomic dysfunction (conjunctival injection, lacrimation, nasal congestion, rhinorrhea, miosis, ptosis) ipsilateral to the pain. Unlike the 
migraine patient, the $\mathrm{CH}$ patient is restless during an attack. Attacks may occur at any time during the day, many times at the same hour for the individual patient. In patients with episodic, but not chronic, $\mathrm{CH}$, a common time for an attack is at night, coinciding with the first REM sleep period [39]. The IHS diagnostic criteria for $\mathrm{CH}$ are listed in Appendix 3.

\section{Pathophysiology}

$\mathrm{CH}$ was previously though to be a "vascular headache". More recent studies, however, show evidence of activation of the trigeminovascular system in $\mathrm{CH}$ [36]. The striking periodicity of $\mathrm{CH}$ attacks has led to the theory of a central generator for $\mathrm{CH}$. Recent evidence for this theory comes from positron emission tomography (PET) studies that show activation of the ipsilateral posterior ventral hypothalamus during $\mathrm{CH}$ attack [40].

\section{Management}

The management of $\mathrm{CH}$ consists of patient support and education, treatment of the acute attack and preventive treatment (Table 4) [36]. Treatment options for the acute attack include inhalation of $100 \%$ oxygen, sumatriptan injections and intravenous DHE. Oxygen should be given at a high flow rate ( $>7$ liter/min) via a non-rebreathing mask for at least 15 minutes. This treatment is very effective, however it is not always readily available. 
Subcutaneous sumatriptan is very effective for the treatment of acute $\mathrm{CH}$ attack, with a response rate of over $70 \%$. DHE is best given intravenously for prompt relief of $\mathrm{CH}$ attack. Since this can not be done at home, this treatment option is less attractive than sumatriptan. Intranasal lidocaine is less effective than the above treatments for acute $\mathrm{CH}$, but may be used as an adjunctive therapy in severe cases [41].

The preventive treatment of $\mathrm{CH}$ is divided into transitional prophylaxis and maintenance prophylaxis. Transitional prophylaxis is given at the beginning of a cluster period in an attempt to prevent attacks until the maintenance preventive drug is effective. This is achieved by either an oral corticosteroid (e.g. prednisone $60 \mathrm{mg} /$ day for three days followed by a gradual taper-off over three weeks) or by oral ergotamine $2 \mathrm{mg}$ /day for 2-3 weeks. Maintenance prophylaxis is given throughout the time of the cluster period. It is started in parallel with the transitional prophylaxis and continued thereafter alone. The drug of choice for maintenance prophylaxis is verapamil. High doses, of up to 720 mg/day, are occasionally needed. Other treatment options include lithium carbonate, methysergide, valproic acid, topiramate and melatonin. A minority of patients who are refractory to medical treatment may need ablative surgical procedures directed at the trigeminal nerve root or ganglion [36]. A novel approach to the preventive treatment of $\mathrm{CH}$ is deep brain stimulation of the posterior-inferior hypothalamus, the area shown to be activated during $\mathrm{CH}$ attacks [42]. Results with this treatment are encouraging but the number of treated patients is still small.

\section{Tension-type headache}


Tension-type headache (TTH) is the most common type of headache. TTH is divided into episodic ( $<15$ days/month) and chronic ( $\geq 15$ days/month) sub-types. In most patients, chronic TTH evolves from episodic TTH.

\section{Epidemiology}

In a Danish population-based study the lifetime prevalence of TTH was as high as $78 \%$ [43]. Many of these patients had short duration or infrequent headaches. Still, $10 \%$ had headache weekly and 2-3\% had it daily. In other studies the prevalence of episodic TTH was $32-35 \%$ and that of chronic (daily or near daily) TTH $-2.2-2.7 \%$ [44] . The prevalence of TTH peaks between the ages of 30 and 39 years and, in contrast to migraine, there is only a slight female preponderance (M:F ratio of 4:5).

\section{Clinical features}

The pain of TTH is typically bilateral, pressing or tightening in quality and of mild to moderate intensity. It is not worsened by routine physical activity. There is no nausea, but photophobia or phonophobia may be present $[6,44]$. According to IHS criteria, the pain of TTH lasts 30 minutes to seven days. Other symptoms include fatigue, sleep disturbances and lightheadedness [45]. There is no aura. The neurologic and physical examination is normal except for pericranial muscle tenderness in some patients. The IHS diagnostic 
criteria for chronic TTH are listed in Appendix 4 (for diagnostic criteria of episodic tension-type headache, see reference 6).

Since both migraine and TTH are very common disorders, they may coexist in an individual patient. As with all primary headaches, the diagnosis of TTH should be made only when secondary causes of headache are not suggested by history or by physical examination. When a secondary headache is suggested, it should be excluded by the appropriate investigation (see Table 1).

\section{Pathophysiology}

Little is known about the pathophysiology of TTH. It is likely that both peripheral and central mechanisms play a role. The increased pericranial muscle tenderness found in many patients with TTH probably represents activation of peripheral nociceptors [46]. Myofascial tenderness was shown to precede the headache and is therefore likely to be involved in the pathogenesis [47]. Changes in central processing of sensory information are also likely to play a role. This is supported by the observation of decreased threshold to pain, thermal and electric stimuli in chronic TTH [48]. There is a higher prevalence of depression and anxiety in patients with chronic TTH, compared with the general population, but this may be secondary to the pain rather than the cause of it.

\section{Management}


Since the basic mechanisms are poorly understood, the treatment of TTH is still not satisfactory. Management includes pharmacologic and non-pharmacologic treatments. For mild to moderate acute episodes, acetaminophen $1000 \mathrm{mg}$ and aspirin (500-1000 mg) are effective [49]. NSAIDs were also shown to be effective in relieving pain of acute TTH and are recommended for moderate to severe pain. Recommended drugs and doses include: ibuprofen 200-400 mg, naproxen 375-550 $\mathrm{mg}$ and diclofenac potassium 12.5-25 mg. Caffeine-containing combination analgesics may be superior to simple analgesics in reliving TTH pain. To avoid medication-overuse headache, the patient should be advised not to overuse acute medications.

The tricyclic antidepressant amitriptyline is the most widely-used drug in the preventive treatment of TTH [50]. Its efficacy has been shown in several well-designed trials and it is considered the drug of choice for this indication. The recommended daily dose is 10-75 mg. The efficacy of the SSRIs in chronic TTH prevention is not well-established. Other potential treatments that need further study include the muscle relaxant tizanidine and botulinum neurotoxin.

Non pharmacologic treatments for TTH include relaxation training, electromyographic biofeedback and cognitive-behavioral therapy. There is well-established evidence for the efficacy of these treatment modalities in TTH [51]. Used either as an adjunct or an alternative to pharmacologic treatment, they reduce headache frequency, affective distress and headache-related disability. These treatments are particularly appealing to 
patients who do not tolerate, do not respond to or have a contraindication to drug treatment.

\section{Medication overuse headache (MOH)}

Patients who suffer from frequent headaches often overuse pain medications [52] . It is estimated that $4 \%$ of the population suffer from chronic daily headache, defined as headache occurring $\geq 15$ day/month, and medication overuse is by far the most common cause of this type of headache[6] [53].

The concept that pain medication over-use may cause or perpetuate chronic daily headache in headache-prone patients has long been recognized [54]. This has been previously termed "rebound headache" or "drug-induced headache". The IHS defined this headache as "medication overuse headache" $(\mathrm{MOH})$ and listed separate diagnostic criteria for headaches caused by each of the major overused drugs (ergotamine, triptans, simple analgesics, opioids and combination analgesics) [6].

Recently, Zwart et al showed in a prospective study of 32067 patients that analgesic overuse is a predictor of having chronic pain and that the risk was highest for patients with migraine [55].

Making the diagnosis of $\mathrm{MOH}$ is extremely important since the primary measure in alleviating this type of headache is to stop the intake of the offending drug. Moreover, it has been shown that acute pain-medication overuse renders migraine preventive drugs less effective or not effective at all [54]. 
In order for a drug to be recognized as a cause of headache, several factors need to be considered: treatment frequency, duration, regularity and dose. These parameters are different for the various drugs, depending on their propensity to cause headache. In general, the treatment frequency required by the IHS is 10-15 days/month, the drug should be taken on a regular basis and the duration of treatment should be $\geq 3$ months. Other important criteria in defining a headache as $\mathrm{MOH}$ are: 1. the headache has developed or markedly worsened during treatment with the drug; and 2. the headache resolves or improves within two months of discontinuation of the drug. Limmroth et al calculated the mean critical treatment duration until the onset of $\mathrm{MOH}(\mathrm{MCDO})$, the mean critical monthly intake frequency (MCMIF) and mean critical monthly dosage (MCMD) in 98 patients with $\mathrm{MOH}$ [56]. They found that MCDO was 1.7, 2.7 and 4.8 years for triptans, ergots and analgesics, respectively. The MCMIF was lowest for triptans (18 doses/month) and highest for analgesics (114 doses/month). They concluded that triptan overuse leads to $\mathrm{MOH}$ faster and with lower doses compared with ergots and analgesics.

\section{Clinical features}

According to IHS definition, MOH should be present in $>15$ days/month. It characteristics vary depending on the type of offending drug. It can be bilateral and pressing/ tightening in quality when simple analgesics or ergotamine are used or it can be unilateral and pulsating when a triptan is used. Its intensity varies from mild to severe. Migraine-associated symptoms may or may not be present. 
The mechanisms by which an analgesic or an anti-migraine drug cause or exacerbate headache are incompletely understood. Continued intake of acute medications may result in resetting the pain control mechanisms in susceptible individuals, perhaps by enhancing central sensitization or by blocking adaptive antinociceptive changes [57].

\section{Management}

The treatment of $\mathrm{MOH}$ consists of discontinuation of the offending drug and then starting the patient on a new pharmacologic regimen without exceeding the limits of drug dose and frequency [58]. Bigal et al studied 456 migraine patients who overused acute medications [59]. At one year follow-up, those patients who stopped overusing acute medications had a $74 \%$ reduction in headache frequency, compared with $17 \%$ for those who continued overusing them. There was also a significantly greater reduction in headache duration and headache intensity in patients who stopped overusing medications compared to those who did not.

During the washout period from the overused drug, headache may temporarily get worse before it gets better. This should be explained to the patient. Other withdrawal symptoms, e.g. nausea, vomiting, agitation, sleep disturbances and rarely, seizures, may occur. This withdrawal period, which last 3-6 weeks, is usually followed by a significant headache improvement.

Detoxification may be done either in an outpatient or an inpatient setting. There are two outpatient strategies for this purpose. One is to taper off the offending drug gradually over 2-3 weeks, substituting it temporarily for a long acting NSAID (e.g. naproxen 
sodium) while an effective longer term preventive therapy is established. The other is to discontinue the offending drug abruptly, substitute it temporarily for an NSAID, prednisone, DHE or a combination of NSAID and tizanidine [58]. An example of such a bridging treatment is naproxen sodium $550 \mathrm{mg}$ twice a day for a week which is tapered off gradually. When butalbital-containing drugs are discontinued abruptly, low-dose phenobarbital (tapering from 60 to $15 \mathrm{mg}$ /day for one week) is given to prevent withdrawal symptoms. During detoxification the patient should be given a rescue medication for acute headache. Drugs used for this purpose are neuroleptics, anti-nausea drugs or opioids (unless the patient is in the process of detoxification from them). When out patient detoxification fails or when there is significant medical or psychiatric comorbidity, inpatient strategies are used. The most widely used drugs for this purpose is repetitive IV DHE with metoclopramide [30]. Alternative treatments used intravenously for patients who have contraindication to or can not tolerate DHE, include chlorpromazine [60], methylprednisolone [61], valproic acid [62] and lidocaine [63] . An important part of management is patient education. The patient should be encouraged to limit acute medication use to the recommended frequency, i.e. for simple analgesics$<15$ days/month and for ergotamine, triptans, opioids and combination analgesics- $<10$ days/month.

\section{Secondary headaches}


Of the many secondary causes of headache, we will discuss cervicogenic headache, which is of particular interest to the anesthesiologist.

\section{Cervicogenic headache}

Cervicogenic headache $(\mathrm{CEH})$ is a term introduced by Sjaastad in 1983 [64]. It is defined as pain perceived in the head whose source lies in the neck [65]. The IHS has accepted $\mathrm{CEH}$ as a type of secondary headache and included it in its Classification of Headache Disorders [6]. In the IHS criteria for CEH diagnosis there is an emphasis on clinical and laboratory evidence for a source of pain in the neck and on abolition of headache following a diagnostic blockade of the presumed source of pain. It did not provide defining criteria for the features of $\mathrm{CEH}$ pain or its associated symptoms (Appendix 5). The criteria of The Cervicogenic Headache International Study Group also include head pain characteristics [66].

The anatomical basis for the concept of headache resulting from cervical pathology lies in neural convergence. Neurons in the dorsal horn of the upper three cervical segments of the spinal cord receive overlapping input from both cervical and trigeminal afferents [67]. Thus, any structure innervated by neurons whose central processes reach the upper three cervical segments may be a source of headache. Clinical studies support this concept. In some patients with headache the pain could be reproduced by stimulation of the C2-C3 intervertebral disc. In other patients, complete headache relief was achieved by anesthetic block of the lateral atlantoaxial joint [68]. 


\section{Epidemiology and clinical features}

The prevalence of $\mathrm{CEH}$ is estimated at $0.4 \%-4.6 \%$. CEH is more common in women compared with men and (female to male ratio 4:1) and the mean age is 42.9 [69].

The hallmark of $\mathrm{CEH}$ is clinical evidence for neck involvement including precipitation of pain by neck movement or external pressure over the neck or occiput; restriction of neck range of motion, and ipsilateral neck, shoulder or arm pain [66]. The pain is typically unilateral without side shifts, starting in the neck and spreading anteriorly to the ipsilateral orbital, frontal and temporal areas. It is initially episodic but often becomes continuous and fluctuating. Pain intensity is usually moderate and it is non-throbbing in character. Nausea, vomiting and photo/phonophobia may occur, but are less frequent and less intense than in migraine. A history of head or neck trauma is common. A positive response to anesthetic block is one of the diagnostic criteria to $\mathrm{CEH}$. These include greater occipital nerve (GON), lesser occipital nerve ( $\mathrm{LON}$ ) and $\mathrm{C}_{2} / \mathrm{C}_{3}$ facet joint blocks. The block should result in elimination or near-elimination of the pain, and the analgesic effect should be demonstrated in non-anesthetized areas. Radiologic findings in CEH are usually non-specific but may help in identifying a cervical pathology that is a potential source of pain (e.g. congenital abnormalities, bone tumors, rheumatoid arthritis, ankylosing spondylitis). Cervical spine osteoarthritis has not been demonstrated to be a cause of CEH.

\section{Management}


The approach to a patient with CEH includes a detailed history, physical and neurologic examination with an emphasis on signs of cervical pathology (local tenderness, limited range of motion and arm weakness, paresthesias or hypoesthesia) and, in some cases, imaging studies to exclude lesions that would require specific therapy (e.g. tumor, rheumatoid arthritis). Anesthetic blockade of a cervical nerve or joint is recommended to support the diagnosis.

The management of CEH includes both pharmacologic and non-pharmacologic components [70].

Pharmacologic treatment has not been evaluated in controlled trials and therefore no evidence-based recommendations can be made. Medications are usually not significantly effective as the sole therapy, and are used as an adjunct to physical and behavioral therapy. Drugs that have been used include the tricyclic antidepressants (amitriptyline, nortriptyline), anticonvulsants (valproic acid, carbamazepine, gabapentin, topiramate), muscle relaxants (tizanidine, baclofen) and NSAIDs. Drugs from the last two groups can be used either for prevention or on an acute basis for pain exacerbation. The other drugs are used for prophylaxis. Cervical epidural injections of corticosteroids may be beneficial in some patients. Botulinum toxin, injected into cervical muscles can be used but its efficacy has not been proven. 
Physical therapy, an important part of CEH therapy, includes muscle stretching and cervical manipulation performed in a gradually progressing manner. Other treatments include biofeedback, relaxation techniques and cognitive-behavioral therapy.

Nerve and anesthetic joint blockade are important in $\mathrm{CEH}$, both as a diagnostic and a therapeutic tool [71] [70] [72]. Possible sites include the GON, LON, $\mathrm{C}_{2} / \mathrm{C}_{3}$ cervical spinal nerves and upper cervical zygapophyseal joints. Anthony found that injection of depot methylprednisolone to the area of the GON and LON resulted in complete headache relief in 169 of 180 patients with CEH [71]. The mean duration of relief was 23.5 days. When an anesthetic block is effective, longer acting neurolytic procedures (e.g. pulsed radiofrequency thermal neurolysis) may be considered. Surgical procedures (neurectomy, dorsal rhizotomy, microvascular decompression of nerve roots) are reserved for patients with clear evidence of a correctable cervical pathology or who are refractory to all other treatment modalities. Nerve stimulation is increasingly used now for these purposes and may gradually replace the ablative procedures in the appropriate cases.

\section{Nerve blocks for the treatment of headaches}

Peripheral nerve blocks have been used to treat headaches for decades $[73,74]$. The most widely used procedure for this purpose is GON block. Other nerve blocks (supraorbital, lesser occipital) are occasionally used. 
The GON is composed of sensory fibers that originate in the $\mathrm{C}_{2}$ and, to a lesser extent, $\mathrm{C}_{3}$ segments of the spinal cord. Its cutaneous sensory distribution is over the posterior part of the head, spreading anteriorly to the vertex. It becomes superficial $2.5-5 \mathrm{~cm}$ inferolateral to the occipital protuberance [75]. There is no standard protocol for GON block procedure. A 23 gauge needle is inserted $3.5 \mathrm{~cm}$ inferolaterally to the occipital protuberance and the nerve is usually infiltrated with a local anesthetic (e.g. of $1 \%-2 \%$ lidocaine or $0.5 \%$ bupivacaine) [76]. At times, a corticosteroid (e.g. triamcinolone) is added.

The rationale for GON block comes from the convergence of sensory input to TNC neurons from both cervical and trigeminal fibers. This may result in alleviation of pain even outside of the GON territory when the nerve is blocked [73].

Supraorbital nerve (SN) block is performed by inserting the needle at the supraorbital notch, which is the point of emergence of this nerve to the epicranial tissue, and infiltrating the area with small volumes of the drugs mentioned above.

Despite their widespread clinical use, the number of studies performed to assess the efficacy of nerve blocks for headache treatment is small $[73,74,77,78]$. Caputi and Firetto found that $85 \%$ of 27 migraine patients responded beneficially to repeated anesthetic blocks [73]. They used $0.5-1$ cc of bupivacaine $0.5 \%$ on alternate days for a maximum of ten blocks. The therapeutic effect was maintained for the entire period of observation (six months) and the treatment was very well tolerated. In another study, the diagnostic value and effects of GON and SN blocks in migraine, TTH and cervicogenic headache patients 
were examined in 52 patients [77]. A single injection of $0.5-1.5 \mathrm{cc}$ of lidocaine $2 \%$ with adrenaline $12.5 \mu \mathrm{g} / \mathrm{ml}$, was used. GON blockade resulted in pain reduction of $54.5 \%$, $14 \%$ and $6 \%$ in the $\mathrm{CEH}$, TTH and migraine groups, respectively. SN blockade resulted in corresponding response rates of $28 \%, 30 \%$ and $16 \%$. Gawel and Rothbart examined the effect of GON block combined with corticosteroid refractory patients with migraine and post-traumatic headache [74]. All patients had been refractory to pharmacologic treatment. Seventy two percent of the post-traumatic headache patients and $54 \%$ of the migraine patients reported being "significantly better" up to six months after the block. Peres et al found that $64 \%$ of $\mathrm{CH}$ patients who were treated with GON block combined with a corticosteroid had good or moderate response [78]. Duration, frequency and intensity of attacks were significantly lower one week after treatment compared with these parameters before treatment. The procedure was very well tolerated. Peripheral nerve blocks are safe and easy-to-perform procedures that are beneficial for some patients with headaches. They appear to be most effective for cervicogenic headache. More studies, however, are needed to evaluate their efficacy in primary headaches and to identify the patients who are most likely to benefit from this treatment.

\section{Summary}

The successful management of headache depends on arriving at a specific diagnosis and not treating the headache as a symptom. It is important to differentiate between primary and secondary headaches and to recognize symptoms and signs that raise suspicion of life-threatening diseases. In the management of primary headaches, emphasis should be 
put on life-style alterations and avoidance of triggers to reduce attack frequency and severity. Acute pharmacologic treatments should be used at the appropriate dosages and time intervals to avoid medication-overuse headache. Using this approach, most headache patients can achieve significant symptomatic relief. 


\section{REFERENCES}

1. Silberstein SD, Saper JR, Freitag F. Migraine: Diagnosis and treatment. In: Silberstein SD, Lipton RB, Dalessio DJ, eds. Wolff's headache and other head pain. 7th ed. New York: Oxford University Press, 2001:121-237.

2. Goadsby PJ, Lipton RB, Ferrari MD. Migraine-current understanding and treatment. N Engl J Med 2002;346:257-270.

3. Stewart WF, Lipton RB, Celentano DD, Reed ML. Prevalence of migraine in the United States. JAMA 1992;267:64-69.

4. Lipton RB, Hamelsky SW, Stewart WF. Epidemiology and impact of headache. In: Silberstein SD, Lipton RB, Dalessio DJ, eds. Wolff's headache and other head pain. 7th ed. New York: Oxford University Press, 2001:85-107.

5. World Health Organization. World Health Report. www.who.int/whr/index.htm . 2001. 7-18-0002. (GENERIC)

Ref Type: Electronic Citation

6. Headache Classification Committee. The International Classification of Headache Disorders, 2nd Edition. Cephalalgia 2004;24:1-160.

7. Silberstein SD, Young WB. Migraine aura and prodrome. Seminars Neurol 1995;45:175-182.

8. Goadsby PJ. Pathophysiology of headache. In: Silberstein SD, Lipton RB, Dalessio DJ, eds. Wolff's headache and other head pain. 7 ed. New York: Oxford University Press, 2001:57-72.

9. Bahra A, Matharu MS, Buchel C, Frackowiak RS, Goadsby PJ. Brainstem activation specific to migraine headache. Lancet 2001;357:1016-1017.

10. Longmore J, Shaw D, Smith D, et al. Differential distribution of 5HT(1D)- and 5HT(1B)-immunoreactivity within the human trigeminocerebrovascular system: implications for the discovery of new antimigraine drugs. Cephalalgia 1997; 17:833-842.

11. Nozaki K, Boccalini P, Moskowitz MA. Expression of c-fos-like immunoreactivity in brainstem after meningeal irritation by blood in the subarachnoid space. Neuroscience 1992;49:669-680.

12. Burstein R, Yarnitsky D, Goor-Aryeh I, Ransil BJ, Bajwa ZH. An association between migraine and cutaneous allodynia. Ann Neurol 2000;47:614-624.

13. Leão AAP. Spreading depression of activity in cerebral cortex. J Neurophysiol 1944;7:359-390. 
14. Olesen J. Cerebral and extracranial circulatory disturbances in migraine: pathophysiological implications. Cerebrovasc Brain Metab Rev 1991;3:1-28.

15. Russell MB. Increased familial risk and evidence of genetic factor in migraine. BMJ 1995;311:541-544.

16. Silberstein SD, Lipton RB, Dalessio DJ. Overview, diagnosis, and classification of headache. In: Silberstein SD, Lipton RB, Dalessio DJ, eds. Wolff's headache and other head pain. 7 ed. New York: Oxford university press, 2001:6-26.

17. Silberstein SD. Practice Parameter--Evidence-based guidelines for migraine headache (an evidence-based review): Report of the Quality Standards Subcommittee of the American Academy of Neurology for the United States Headache Consortium. Neurology 2000;55:754-762.

18. Burstein R, Collins B, Jakubowski M. Defeating migraine pain with triptans: a race against the developing allodynia. Ann Neurol 2004;55:19-26.

19. Cady RK, Sheftell F, Lipton RB, et al. Effect of early intervention with sumatriptan on migraine pain: retrospective analyses of data from three clinical trials. Clin Therap 2000;22:1035-1048.

20. Silberstein SD, McCrory DC. Opioids. Cephalalgia 2000;20:854-864.

21. Colman I, Rothney A, Wright SC, Zilkalns B, Rowe BH. Use of narcotic analgesics in the emergency department treatment of migraine headache. Neurology 2004;62:1695-1700.

22. Saper JR, Lake AE, Hamel RL, et al. Daily scheduled opioids for intractable head pain: long-term observations of a treatment program. Neurology 2004;62:16871694.

23. Jones J, Sklar D, Dougherty J, White W. Randomized double-blind trial of intravenous prochlorperazine for the treatment of acute headache. JAMA 1989;261:1174-1176.

24. Bigal ME, Bordini CA, Speciali JG. Intravenous chlorpromazine in the emergency department treatment of migraines: a randomized controlled trial. J Emerg Med 2002;23:141-148.

25. Schulman EA, Dermott KF. Sumatriptan plus metoclopramide in triptannonresponsive migraineurs. Headache 2003;43:729-733.

26. Silberstein SD, Young WB, Mendizabal JE, Rothrock JF, Alam AS. Acute migraine treatment with droperidol: a randomized, double-blind, placebocontrolled trial. Neurology 2003;60:315-321. 
27. Food and Drug Administration. http://www.fdaadvisorycommittee.com . 2004. (GENERIC)

Ref Type: Electronic Citation

28. Ashkenazi A, Silberstein SD. The evolving management of migraine. Curr Opin Neurol 2003;16:341-345.

29. Silberstein SD, McCrory DC. Ergotamine and dihydroergotamine: history, pharmacology, and efficacy. Headache 2003;43:144-166.

30. Raskin NH. Repetitive intravenous dihydroergotamine as therapy for intractable migraine. Neurology 1986;36:995-997.

31. Welch KM, Mathew NT, Stone P, Rosamond W, Saiers J, Gutterman D. Tolerability of sumatriptan: clinical trials and postmarketing experience. Cephalalgia 2000;20:687-694.

32. Silberstein SD, Goadsby PJ. Migraine: preventive treatment. Cephalalgia 2002;22:491-512.

33. Ramadan, N. M., Silberstein, S. D., Freitag, F. G., Gilbert, T. T., and Frishberg, B. Evidence-based guidelines of the pharmacological management for prevention of migraine for the primary care provider. Neurology . 1999. (GENERIC)

Ref Type: Electronic Citation

34. Ashkenazi A, Silberstein SD. Botulinum toxin and other new approaches to migraine therapy. Annu Rev Med 2004;55:505-518.

35. Campbell, J. K., Penzien, D., and Wall, E. M. Evidenced-based guidelines for migraine headache: behavioral and physical treatments. http://www.neurology.org . 2000. (GENERIC)

Ref Type: Electronic Citation

36. Dodick DW, Campbell JK. Cluster headache: diagnosis, management, and treatment. In: Silberstein SD, Lipton RB, Dalessio D, eds. Wolff's Headache and Other Head Pain. 7th ed. New York: Oxford University Press, 2001:283-309.

37. May A, Leone M. Update on cluster headache. Curr Opin Neurol 2003;16:333340.

38. Finkel AG. Epidemiology of cluster headache. Curr Pain Headache Rep 2003;7:144-149.

39. Pfaffenrath V, Pollmann W, Ruther E, Lund R, Hajak G. Onset of nocturnal attacks of chronic cluster headache in relation to sleep stages. Acta Neurol Scand 1986;73:403-407. 
40. May A, Bahra A, Buchel C, Frackowiak RS, Goadsby PJ. Hypothalamic activation in cluster headache attacks. Lancet 1998;352:275-278.

41. Robbins L. Intranasal lidocaine for cluster headache. Headache 1995;35:83-84.

42. Leone M, Franzini A. Stereotactic stimulation of the posterior hypothalamic gray matter in a patient with intractable cluster headache. N Eng J Med 2001;345:1428-1429.

43. Rasmussen BK, Jensen R, Schroll M, Olesen J. Epidemiology of headache in a general population-a prevalence study. J Clin Epidemiol 1991;44:1147-1157.

44. Jensen R. Diagnosis, epidemiology, and impact of tension-type headache. Curr Pain Headache Rep 2003;7:455-459.

45. Rasmussen BK. Migraine and tension-type headache in a general population: precipitating factors, female hormones, sleep pattern, and relation to lifestyle. Pain 1993;53:65-72.

46. Jensen R. Peripheral and central mechanisms in tension-type headache: an update. Cephalalgia 2003;23 Suppl 1:49-52.

47. Jensen R, Olesen J. Tension-type headache: an update on mechanisms and treatment. Curr Opin Neurol 2000;13:285-289.

48. Bendtsen L, Jensen R, Olesen J. Decreased pain detection and tolerance thresholds in chronic tension-type headache. Arch Neurol 1996;53:373-376.

49. Ashina S, Ashina M. Current and potential future drug therapies for tension-type headache. Curr Pain Headache Rep 2003;7:466-474.

50. Mathew NT, Bendtsen L. Prophylactic pharmacotherapy of tension-type headache. In: Olesen J, Tfelt-Hansen P, Welch KMA, eds. The headaches. 2nd ed. Philadelphia: Lippincott Williams \& Wilkins, 2000:667-673.

51. Nash JM. Psychologic and behavioral management of tension-type headache: treatment procedures. Curr Pain Headache Rep 2003;7:475-481.

52. Silberstein SD, Lipton RB. Chronic daily headache including transformed migraine, chronic tension-type headache, and medication overuse. In: Silberstein SD, Lipton RB, Dalessio DJ, eds. Wolff's headache and other head pain. Seventh ed. New York: Oxford University Press, 2001:247-282.

53. Scher AI, Stewart WF, Liberman J, Lipton RB. Prevalence of frequent headache in a population sample. Headache 1998;38:497-506.

54. Mathew NT, Kurman R, Perez F. Drug induced refractory headache - clinical features and management. Headache 1990;30:634-638. 
55. Zwart JA, Dyb G, Hagen K, Svebak S, Holmen J. Analgesic use: a predictor of chronic pain and medication overuse headache: the Head-HUNT Study. Neurology 2003;61:160-164.

56. Limmroth V, Katsarava Z, Fritsche G, Przywara S, Diener HC. Features of medication overuse headache following overuse of different acute headache drugs. Neurology 2002;59:1011-1014.

57. Post RM, Silberstein SD. Shared mechanisms in affective illness, epilepsy, and migraine. Neurology 1994;44:S37-S47

58. Young WB. Drug-induced headache. Neurol Clin N Am 2004;22:173-184.

59. Bigal M, Rapoport A, Sheftell F, Tepper S, Lipton R. Transformed migraine and medication overuse in a tertiary headache centre - clinical characteristics and treatment outcomes. Cephalalgia 2004;24:483-490.

60. Ashkenazi A, Levin M, Ward TN: Treatment of chronic daily headache with intravenous chlorpromazine. Headache 2002;42:427(Abstract)

61. Rozen TD. Migraine Headache: Immunosuppressant Therapy. Curr Treat Options Neurol 2002;4:395-401.

62. Mathew NT, Kailasam J: Repetitive intravenous administration of valproate sodium in intractable migraine: comparison with intravenous dihydroergotamine (DHE). Neurology 2000;54:A22(Abstract)

63. Williams DR, Stark RJ. Intravenous lignocaine (lidocaine) infusion for the treatment of chronic daily headache with substantial medication overuse. Cephalalgia 2003;23:963-971.

64. Sjaastad O, Saumte C, Hovdahl H. Cervicogenic headache, a hypothesis. Cephalalgia 1983;3:249-256.

65. Edmeads JG. Disorders of the neck: cervicogenic headache. In: Silberstein SD, Lipton RB, Dalessio DJ, eds. Wolff's headache and other head pain. Seventh ed. New York: Oxford University Press, 2001:447-458.

66. Sjaastad O, Fredriksen TA, Pfaffenrath V. Cervicogenic headache: diagnostic criteria. The Cervicogenic Headache International Study Group. Headache 1998;38:442-445.

67. Bogduk N. Cervicogenic headache: anatomic basis and pathophysiologic mechanisms. Curr Pain Headache Rep 2001;5:382-386.

68. Ehni G, Benner B. Occipital neuralgia and the $\mathrm{C} 1-2$ arthrosis syndrome. J Neurosurg 1984;61:961 
69. Haldeman S, Dagenais S. Cervicogenic headaches: a critical review. Spine J 2001;1:31-46.

70. Biondi DM. Cervicogenic headache: diagnostic evaluation and treatment strategies. Curr Pain Headache Rep 2001;5:361-368.

71. Anthony M. Cervicogenic headache: prevalence and response to local steroid therapy. Clin Exp Rheumatol 2000;18:S59-S64

72. Silverman SB. Cervicogenic headache: interventional, anesthetic, and ablative treatment. Curr Pain Headache Rep 2002;6:308-314.

73. Caputi CA, Firetto V. Therapeutic blockade of greater occipital and supraorbital nerves in migraine patients. Headache 1997;37:174-179.

74. Gawel MJ, Rothbart PJ. Occipital nerve block in the management of headache and cervical pain. Cephalalagia 1992;12:9

75. Rothbart P. Re: Caputi CA, Firetto V. Therapeutic blockade of the greater occipital and supraorbital nerves in migraine patients. Headache 1998;38:56

76. Ward JB. Greater occipital nerve block. Semin Neurol 2003;23:59-62.

77. Bovim G, Sand T. Cervicogenic headache, migraine without aura and tensiontype headache. Diagnostic blockade of greater occipital and supra-orbital nerves. Pain 1992;51:43-48.

78. Peres MF, Stiles MA, Siow HC, Rozen TD, Young WB, Silberstein SD. Greater occipital nerve blockade for cluster headache. Cephalalgia 2002;22:520-522. 
Table 1: Worrisome symptoms, signs and clinical settings in the patient with headache

Abbreviations: IIH - idiopathic intracranial hypertension; AVM - arteriovenous malformation; CVT- cortical vein thrombosis; MRV - magnetic resonance venography

\begin{tabular}{|c|c|c|}
\hline $\begin{array}{l}\text { Symptom, sign or } \\
\text { clinical setting }\end{array}$ & Differential diagnosis & Work-up \\
\hline $\begin{array}{l}\text { Headache after the age of } \\
50\end{array}$ & $\begin{array}{l}\text { Temporal arteritis; } \\
\text { Intracranial tumor }\end{array}$ & ESR, neroimaging \\
\hline Hyperacute headache & $\begin{array}{l}\text { Subarachnoid hemorrhage; } \\
\text { Intracerebral hemorrhage }\end{array}$ & $\begin{array}{l}\text { Neuroimaging, lumbar } \\
\text { puncture }\end{array}$ \\
\hline Worst headache ever & $\begin{array}{l}\text { Subarachnoid hemorrhage; } \\
\text { Meningitis }\end{array}$ & $\begin{array}{l}\text { Neuroimaging, lumbar } \\
\text { puncture }\end{array}$ \\
\hline $\begin{array}{l}\text { Progressively-worsening } \\
\text { headache }\end{array}$ & $\begin{array}{l}\text { Intracranial tumor or other } \\
\text { space occupying lesion }\end{array}$ & Neuroimaging \\
\hline $\begin{array}{l}\text { Headache in a patient } \\
\text { with cancer or AIDS }\end{array}$ & $\begin{array}{l}\text { Chronic or subacute } \\
\text { meningitis; Meningeal } \\
\text { carcinomatosis; Brain } \\
\text { metastases; CNS } \\
\text { lymphoma; Brain abscess }\end{array}$ & $\begin{array}{l}\text { Neuroimaging, lumbar } \\
\text { puncture }\end{array}$ \\
\hline $\begin{array}{l}\text { Headache with fever or } \\
\text { rash }\end{array}$ & Meningitis & $\begin{array}{l}\text { Lumbar puncture, blood } \\
\text { and CSF serology }\end{array}$ \\
\hline $\begin{array}{l}\text { Headache with } \\
\text { papilledema }\end{array}$ & $\begin{array}{l}\text { Brain tumor or abscess; } \\
\text { Dural sinus thrombosis; } \\
\text { IIH }\end{array}$ & $\begin{array}{l}\text { Neuroimaging including } \\
\text { MRV, lumbar puncture }\end{array}$ \\
\hline $\begin{array}{l}\text { Headache with focal } \\
\text { neurologic signs }\end{array}$ & $\begin{array}{l}\text { Brain tumor or abscess, } \\
\text { AVM; Stroke; CVT; CNS } \\
\text { Vasculitis }\end{array}$ & $\begin{array}{l}\text { Neuroimaging including } \\
\text { MRV, lumbar puncture, } \\
\text { blood tests for } \\
\text { autoantibodies }\end{array}$ \\
\hline
\end{tabular}


Table 2: The triptans

\begin{tabular}{|c|c|c|c|c|}
\hline Drug & Route & Dose & Max dose per day & Comments \\
\hline \multirow[t]{3}{*}{ Sumatriptan } & Oral & $\begin{array}{l}50 \mathrm{mg} \\
100 \mathrm{mg}\end{array}$ & $200 \mathrm{mg}$ & $\begin{array}{l}\text { The triptan that has } \\
\text { been used for the } \\
\text { longest period of } \\
\text { time }\end{array}$ \\
\hline & Nasal spray & $\begin{array}{l}5 \mathrm{mg} \\
20 \mathrm{mg}\end{array}$ & $40 \mathrm{mg}$ & $\begin{array}{l}\text { More rapid onset of } \\
\text { action then the oral } \\
\text { formulation }\end{array}$ \\
\hline & Injection (s.c.) & $6 \mathrm{mg}$ & $12 \mathrm{mg}$ & $\begin{array}{l}\text { Most rapid onset of } \\
\text { action; highest } \\
\text { efficacy }\end{array}$ \\
\hline \multirow[t]{2}{*}{ Zolmitriptan } & Oral & $\begin{array}{l}2.5 \mathrm{mg} \\
5 \mathrm{mg}\end{array}$ & $10 \mathrm{mg}$ & \multirow{2}{*}{$\begin{array}{l}\text { Efficacy and } \\
\text { tolerability similar } \\
\text { to sumatriptan }\end{array}$} \\
\hline & $\begin{array}{l}\text { Orally- } \\
\text { dissolved }\end{array}$ & $\begin{array}{l}2.5 \mathrm{mg} \\
5 \mathrm{mg}\end{array}$ & & \\
\hline \multirow[t]{2}{*}{ Rizatriptan } & Oral & $\begin{array}{l}5 \mathrm{mg} \\
10 \mathrm{mg}\end{array}$ & $30 \mathrm{mg}$ & \multirow{2}{*}{$\begin{array}{l}\text { Reduce dose by } \\
50 \% \text { when taken } \\
\text { with propranolol }\end{array}$} \\
\hline & $\begin{array}{l}\text { Orally- } \\
\text { dissolved }\end{array}$ & $\begin{array}{l}5 \mathrm{mg} \\
10 \mathrm{mg}\end{array}$ & & \\
\hline Naratriptan & Oral & $\begin{array}{l}1 \mathrm{mg} \\
2.5 \mathrm{mg}\end{array}$ & $5 \mathrm{mg}$ & $\begin{array}{l}\text { Long half life }(6 \mathrm{~h}) \\
\text { few adverse events }\end{array}$ \\
\hline Almotriptan & Oral & $\begin{array}{l}6.25 \mathrm{mg} \\
12.5 \mathrm{mg}\end{array}$ & $25 \mathrm{mg}$ & $\begin{array}{l}\text { Efficacy similar to } \\
\text { sumatriptan, slightly } \\
\text { better tolerability }\end{array}$ \\
\hline Frovatriptan & Oral & $2.5 \mathrm{mg}$ & $7.5 \mathrm{mg}$ & $\begin{array}{l}\text { Longest half life } \\
(25 \mathrm{~h})\end{array}$ \\
\hline Eletriptan & Oral & $\begin{array}{l}20 \mathrm{mg} \\
40 \mathrm{mg}\end{array}$ & $80 \mathrm{mg}$ & $\begin{array}{l}\text { High bioavailability } \\
\text { and efficacy }\end{array}$ \\
\hline
\end{tabular}


Table 3: Preventive drug treatment for migraine Abbreviations: CHF - congestive heart failure; PVD - peripheral vascular disease; DM diabetes mellitus

\begin{tabular}{|c|c|c|c|c|}
\hline Drug group & Drug & Daily dose & Side effects & $\begin{array}{l}\text { Contraindications/ } \\
\text { comments }\end{array}$ \\
\hline \multirow{2}{*}{$\begin{array}{l}\beta \text {-adrenergic } \\
\text { blockers }\end{array}$} & Propranolol & $80-240 \mathrm{mg}$ & \multirow{2}{*}{$\begin{array}{l}\text { Fatigue, sleep } \\
\text { disorders, } \\
\text { impotence, } \\
\text { depression, } \\
\text { orthostatic } \\
\text { symptoms }\end{array}$} & \multirow{2}{*}{$\begin{array}{l}\text { Asthma, CHF, } \\
\text { PVD, DM }\end{array}$} \\
\hline & Metoprolol & $100-200 \mathrm{mg}$ & & \\
\hline \multirow[t]{3}{*}{ Antidepressants } & Amitriptyline & $10-75 \mathrm{mg}$ & $\begin{array}{l}\text { Sedation, weight } \\
\text { gain, dry mouth }\end{array}$ & $\begin{array}{l}\text { Urinary retention, } \\
\text { mania }\end{array}$ \\
\hline & Fluoxetine & $10-80 \mathrm{mg}$ & $\begin{array}{l}\text { Anxiety, } \\
\text { insomnia, } \\
\text { sexual } \\
\text { dysfunction }\end{array}$ & mania \\
\hline & Phenelzine & $30-90 \mathrm{mg}$ & $\begin{array}{l}\text { Insomnia, weight } \\
\text { gain, peripheral } \\
\text { edema }\end{array}$ & $\begin{array}{l}\text { Concomitant } \\
\text { sympathomimetic } \\
\text { drugs; avoid } \\
\text { tyramine- } \\
\text { containing foods }\end{array}$ \\
\hline \multirow[t]{2}{*}{ Anticonvulsants } & $\begin{array}{l}\text { Divalproex } \\
\text { sodium }\end{array}$ & $800-1200 \mathrm{mg}$ & $\begin{array}{l}\text { Sedation, tremor, } \\
\text { alopecia, weight } \\
\text { gain, } \\
\text { hepatotoxicity }\end{array}$ & $\begin{array}{l}\text { Liver disease, } \\
\text { pregnancy, } \\
\text { hematologic } \\
\text { disorders }\end{array}$ \\
\hline & Topiramate & $100-400 \mathrm{mg}$ & $\begin{array}{l}\text { Paresthesias, } \\
\text { fatigue, weight } \\
\text { loss, cognitive } \\
\text { impairment }\end{array}$ & Renal stones \\
\hline \multirow[t]{2}{*}{$\begin{array}{l}\text { Calcium } \\
\text { channel } \\
\text { blockers }\end{array}$} & Flunarizine & $5-15 \mathrm{mg}$ & $\begin{array}{l}\text { Fatigue, weight } \\
\text { gain, depression, } \\
\text { parkinsonism }\end{array}$ & $\begin{array}{l}\text { Extra-pyramidal } \\
\text { disorders }\end{array}$ \\
\hline & Verapamil & $160-320 \mathrm{mg}$ & $\begin{array}{l}\text { Constipation, } \\
\text { peripheral edema }\end{array}$ & $\begin{array}{l}\text { Heart block, } \\
\text { hypotension }\end{array}$ \\
\hline $\begin{array}{l}\text { Serotonin } \\
\text { antagonists }\end{array}$ & Methysergide & $1-6 \mathrm{mg}$ & $\begin{array}{l}\text { Myalgia, nausea, } \\
\text { weight gain, } \\
\text { fibrosis }\end{array}$ & $\begin{array}{l}\text { Stop treatment } \\
\text { every } 6 \text { months for } \\
4 \text { weeks. }\end{array}$ \\
\hline
\end{tabular}


Table 4: Pharmacologic treatment of cluster headache

AEs - adverse events

\begin{tabular}{|c|c|c|c|c|}
\hline $\begin{array}{l}\text { Treatment } \\
\text { type }\end{array}$ & Drug & Route & Dose & Comments \\
\hline \multirow[t]{3}{*}{ Acute } & Oxygen $100 \%$ & $\begin{array}{l}\text { Non- } \\
\text { rebreathing } \\
\text { mask }\end{array}$ & $\begin{array}{l}>7 \mathrm{~L} / \mathrm{min} \text { for } \\
15 \mathrm{~min}\end{array}$ & $\begin{array}{l}\text { Effective but not } \\
\text { always readily } \\
\text { available }\end{array}$ \\
\hline & Sumatriptan & $\begin{array}{l}\text { Injectable } \\
\text { (s.c.) }\end{array}$ & $6 \mathrm{mg}$ & Very effective \\
\hline & Dihydroergotamine & $\begin{array}{l}\text { Injectable } \\
\text { (i.v.) }\end{array}$ & $1 \mathrm{mg}$ & $\begin{array}{l}\text { Not available at } \\
\text { home }\end{array}$ \\
\hline \multirow[t]{2}{*}{$\begin{array}{l}\text { Preventive- } \\
\text { transitional }\end{array}$} & Prednisone & oral & $\begin{array}{l}60 \mathrm{mg} / \mathrm{day}, \\
\text { taper } \\
\text { gradually }\end{array}$ & $\begin{array}{l}\text { Multiple potential } \\
\text { AEs }\end{array}$ \\
\hline & Ergotamine & oral & $2 \mathrm{mg} / \mathrm{day}$ & $\begin{array}{l}\text { Can not be given } \\
\text { with triptans }\end{array}$ \\
\hline \multirow[t]{6}{*}{$\begin{array}{l}\text { Preventive- } \\
\text { maintenance }\end{array}$} & Verapamil & oral & $\begin{array}{l}240-720 \\
\mathrm{mg} / \text { day }\end{array}$ & Monitor ECG \\
\hline & Lithium carbonate & oral & $\begin{array}{l}600-900 \\
\text { mg/day }\end{array}$ & $\begin{array}{l}\text { Monitor drug } \\
\text { levels, kidney and } \\
\text { thyroid functions }\end{array}$ \\
\hline & Methysergide & oral & $2-12 \mathrm{mg} /$ day & $\begin{array}{l}\text { Can not be used } \\
\text { with ergots }\end{array}$ \\
\hline & Valproic acid & oral & $\begin{array}{l}500-2000 \\
\mathrm{mg} / \text { day }\end{array}$ & $\begin{array}{l}\text { Monitor drug blood } \\
\text { levels, LFTs and } \\
\text { CBC }\end{array}$ \\
\hline & Topiramate & oral & $\begin{array}{l}50-125 \\
\mathrm{mg} / \text { day }\end{array}$ & $\begin{array}{l}\text { Potential cognitive } \\
\text { AEs and renal } \\
\text { calculi }\end{array}$ \\
\hline & Melatonin & oral & $10 \mathrm{mg}$ & Few AEs \\
\hline
\end{tabular}


Appendix 1: IHS diagnostic criteria for migraine without aura

\subsection{Migraine without aura}

A. At least 5 attacks fulfilling criteria B-D

B. Headache attacks lasting 4-72 hours (untreated or unsuccessfully treated)

C. Headache has at least two of the following characteristics:

1. unilateral location

2. pulsating quality

3. moderate or severe pain intensity

4. aggravation by or causing avoidance of routine physical activity (eg, walking or climbing stairs)

D. During headache at least one of the following:

1. nausea and/or vomiting

2. photophobia and phonophobia

E. Not attributed to another disorder

Appendix 2: IHS diagnostic crieteria for migraine with aura

\subsection{Migraine with aura}

A. At least 2 attacks fulfilling criterion $\mathrm{B}$

B. Migraine aura fulfilling criteria B and C for one of the subforms 1.2.1-1.2.6

C. Not attributed to another disorder

\subsubsection{Typical aura with migraine headache}

A. At least 2 attacks fulfilling criteria B-D

B. Aura consisting of at least one of the following, but no motor weakness:

1. fully reversible visual symptoms including positive features ( $\mathrm{eg}$, flickering lights, spots or lines) and/or negative features (ie, loss of vision)

2. fully reversible sensory symptoms including positive features (ie, pins and needles) and/or negative features (ie, numbness)

3. fully reversible dysphasic speech disturbance

C. At least two of the following:

1. homonymous visual symptoms and/or unilateral sensory symptoms

2. at least one aura symptom develops gradually over $\geq 5$ minutes and/or different aura symptoms occur in succession over $\geq 5$ minutes

3. each symptom lasts $\geq 5$ and $\leq 60$ minutes 

D. Headache fulfilling criteria B-D for 1.1 Migraine without aura begins during the aura or follows aura within 60 minutes
E. Not attributed to another disorder

Appendix 3: IHS diagnostic criteria for cluster headache

\subsection{Cluster headache}

A. At least 5 attacks fulfilling criteria B-D

B. Severe or very severe unilateral orbital, supraorbital and/or temporal pain lasting 15180 minutes if untreated

C. Headache is accompanied by at least one of the following:

1. ipsilateral conjunctival injection and/or lacrimation

2. ipsilateral nasal congestion and/or rhinorrhoea

3. ipsilateral eyelid oedema

4. ipsilateral forehead and facial sweating

5. ipsilateral miosis and/or ptosis

6. a sense of restlessness or agitation

D. Attacks have a frequency from one every other day to 8 per day

E. Not attributed to another disorder

Appendix 4: IHS diagnostic criteria for chronic tension-type headache

\subsection{Chronic tension-type headache}

A. Headache occurring on $\geq 15$ days per month on average for $>3$ months ( $\geq 180$ days per year) and fulfilling criteria B-D

B. Headache lasts hours or may be continuous

C. Headache has at least two of the following characteristics:

1. bilateral location

2. pressing/tightening (non-pulsating) quality

3. mild or moderate intensity

4. not aggravated by routine physical activity such as walking or climbing stairs

D. Both of the following:

1. no more than one of photophobia, phonophobia or mild nausea

2. neither moderate or severe nausea nor vomiting

E. Not attributed to another disorder 
Appendix 5: IHS diagnostic criteria for cervicogenic headache

\subsubsection{Cervicogenic headache}

A. Pain, referred from a source in the neck and perceived in one or more regions of the head and/or face, fulfilling criteria $\mathrm{C}$ and $\mathrm{D}$

B. Clinical, laboratory and/or imaging evidence of a disorder or lesion within the cervical spine or soft tissues of the neck known to be, or generally accepted as, a valid cause of headache

C. Evidence that the pain can be attributed to the neck disorder or lesion based on at least one of the following:

1. demonstration of clinical signs that implicate a source of pain in the neck ${ }^{2}$

2. abolition of headache following diagnostic blockade of a cervical structure or its nerve supply using placebo- or other adequate controls ${ }^{3}$

D. Pain resolves within 3 months after successful treatment of the causative disorder or lesion

Appendix 6: The Cervicogenic Headache International Study Group diagnostic criteria for cervicogenic headache

I. Symptoms and signs of neck involvement:

a. precipitation of head pain similar to the usually occurring one:

1. by neck movement and/or sustained awkward head positioning, and/or

2 . by external pressure over the upper cervical or occipital region on the symptomatic side

b. restriction of the range of motion (ROM) in the neck

c. ipsilateral neck, shoulder or arm pain of a rather vague nonradicular nature or occasionally arm pain of a radicular nature

II. Confirmatory evidence by diagnostic anesthetic blockades

III. Unilaterality of the head pain, without side shift 